\title{
The Clustering Process in Latvia and Existing Problems
}

\author{
Elena Zaitseva \\ Faculty of Regional Economy, Baltic International Academy, Latvia
}

Copyright $(2016$ by authors, all rights reserved. Authors agree that this article remains permanently open access under the terms of the Creative Commons Attribution License 4.0 International License

\begin{abstract}
Clustering in many countries contributes to the economic development of the states. But the clustering process, as well as its policy has its disadvantages which form the level of economic success of the state. Small EU countries, such as Latvia are particularly subjected to the negative subsequences of carried out economic reforms that makes more thoroughly to study the negative factors of clustering process.
\end{abstract}

Keywords Clustering Process, Development of the Economy, Economic Policy

\section{JEL Classification: R11, R58}

\section{Introduction}

Established classical approaches to economic development are rapidly losing their relevance and effectiveness. Therefore, in the last decade the interest to the clustering process of the economy has grown significantly. The majority of developed countries of the world use the cluster model of development as it leads to an increase in investments, development of innovations, and extension of sales markets and so on. The economy clustering steadily holds the first places in the modern discussions, concerning the establishment of competitive advantages of countries, regions and industries.

At the same time, the clustering process in Latvia hampered by an insufficient level of governance. Latvia during the ten-year stay in the EU has received investments from various funds, but they poorly promoted clustering, both core and related economy sectors.

Latvia should create the conditions for growing the clusters of industries, contributing to the increase of competitiveness of the national economy as a whole. This aspect is very topical for Latvia, since the creation of favorable conditions can give a powerful impact to the development of industries, enterprises, organizations, directly related and defining better image and standard of living of the people, their welfare and consumption. The author believes that in Latvia there is a dangerous economic situation - loss of economic independence and security. Therefore, there is provided a number of recommendations, which, in your opinion, will contribute to the implementation of the cluster policy.

The considered issues in this article are not including the whole list of issues that impede the process of clustering of Latvia. But even they are the brake of development of innovative economy of the country.

\section{Brief Literature Review}

One of the first the term "cluster" was used by the American economist M. Porter (1990), according to his theory - it is a group of geographically adjacent interrelated companies and associated organizations, operating in a particular field, characterized by common activity and mutually reinforcing of each other [1].

The beginning of the cluster approach can be traced in the works of the following economists: A. Marshall (the economy of agglomerations and industrial area) justification of connection between the productivity of firms and their geographic concentration, where in high transport costs occur the dispersal of industries by regions and at lower - the location of firms near each other, and J. Schumpeter (innovations, contributing to the economic growth and development).

In modern economic literature is increasingly common the division of literature not by sectors and industries, but by clusters. Accordingly, clusters, success of which is determined by the going processes within the national states and effective use of local peculiarities, represent an important source of increasing of economic welfare of the country. Cluster is one of the main factors of growth of internal market and international expansion.

The cluster theory of Swedish theorists basically is formed on the study of correlations of Swedish corporations. Here clusters are based on the thesis of E. Dahmen "about the blocks of development". The basis for the development of competitive success he considers the existence of connection between the ability of one sector to develop and ability to provide a progress in another one [2].

On the formation of clusters in not only formal but also informal, personal relationships between the participants, written Danish scientists Van den Berg L and Erik Braun. They note that such relationships facilitate doing business and help coordinate efforts in an ever-changing environment $[3]$. 
In general, the above mentioned, authors are agreeing on one thing that the existence of clusters allows the national industries to develop and support their competitive advantage.

\section{The Main Results of the Research}

EU support clustering Latvia. For opportunity of development of cluster innovative concept of Latvia and other EU countries, a number of organizations is formed by the European Commission that provide educational, information, consulting, as well as marketing support to territorial clusters, including: European Cluster Observatory, European Cluster Policy Group, European Cluster Alliance, Cluster Innovation Platform.

In accordance with the strategy "Europe - 2020", where clusters are defined as a tool of innovation and industrial policy, capable "to prepare Europe for global competition", the European Commission and other supranational structures of the EU strongly recommend to the countries to develop transnational inter-cluster relations and focus on the formation of world - class clusters.

In the European Community there is a serious concern about the fact that investments of the countries of community in scientific and technological development inferior to the US and Japan investments. According to the opinion of the European Commission, the EU has a chance to amend the situation, if it pools resources of their countries, in each of which a national scientific policy will be reformed in accordance with the common European standard. An important role in this is given to the development of clusters both within countries and within the EU frameworks. For Latvia there is a cluster program under which is allocated 4.8 million Euro for the development of cluster initiatives and their support - to promote cooperation between unrelated companies operating in specified sectors and research, educational and other institutions, thus promoting increase of export volumes and competitiveness of entrepreneurs as well as development of new products. And the instruments to support internationalization Activities of clusters - training, funding, match-making and study trips [4].

In Latvia are created the following clusters - Latvian wood and construction cluster, Russian cluster, the cluster of Product Quality, Life Science Cluster of Latvia, CleanTech Latvia, Latvian IT cluster, the Latvian cluster of Health Tourism, the cluster of long-term Tourism of Latvia, the Ventspils Hi-tech Park is established, which has become the first stimulant of the Latvian clusters with the opportunity to enter the international and regional markets for entrepreneurs.

The main problems in clustering Latvia. Note that according to the statistics, in Latvia are $95 \%$ of the economically active units have the status of micro and small enterprises, but the large and small enterprises make only $5 \%$. And as in the world practice emerges a tendency - the concentration of the company on the principal directions and delegation of production of intermediate product and the field of key services to other, including small enterprises, taking into the consideration this trend of creation of clusters has a powerful influence on small business. However, no matter how important are motivations to unification in clusters, many small enterprises are characterized by individualism [5], which is especially pronounced in Latvia.

As in cluster the innovation component occupies a significant part, then, it is worth noting that in the Latvian economy it is developing extremely slowly. The formed nature of the state management in Latvia doesn't contribute to the required level of innovative development and is not able to provide sufficiently the competitiveness of production of domestic manufacturers that generates an extremely low efficiency of innovative activity. The result of this is a preferential concentration of capital in large state and private corporations which are able more successfully to attract investments and financing. Despite the increase of financing of research works and innovative development of Latvia on the part of the EU, the index of innovativeness ranges from 0,19 to 0,26 , while the index of the EU - in the range of $0,45-0,55$ [6].

Here it is possible to show the indicator of the government of Latvia (Finland background information), where the nature and quality of management of the country are revealed that of course, in a certain way responds to the support of cluster initiatives, etc. (Table1).

Table 1. Worldwide Governance Indicator (2014). Latvia and Finland (reference)

\begin{tabular}{|c|c|c|c|c|}
\hline Indicator & Country & $\begin{array}{c}\text { Governance Score } \\
(-2.5 \text { to }+2.5)\end{array}$ & $\begin{array}{l}\text { Percentile Rank } \\
\quad(0 \text { to 100) }\end{array}$ & Standard Error \\
\hline \multirow{2}{*}{ Voice and Accountability } & Finland & 1,6 & 98,0 & 0,1 \\
\hline & Latvia & 0,8 & 71,9 & 0,1 \\
\hline \multirow{2}{*}{$\begin{array}{c}\text { Political Stability and Absence of } \\
\text { Violence/Terrorism }\end{array}$} & Finland & 1,3 & 95,6 & 0,2 \\
\hline & Latvia & 0,6 & 65,0 & 0,2 \\
\hline \multirow{2}{*}{ Government Effectiveness } & Finland & 2,0 & 99,0 & 0,2 \\
\hline & Latvia & 1,0 & 77,9 & 0,2 \\
\hline \multirow{2}{*}{ Regulatory Quality } & Finland & 1,9 & 98,6 & 0,2 \\
\hline & Latvia & 1,2 & 84,6 & 0,2 \\
\hline \multirow{2}{*}{ Rule of Law } & Finland & 2,1 & 100,0 & 0,2 \\
\hline & Latvia & 0,9 & 77,9 & 0,1 \\
\hline \multirow{2}{*}{ Control of Corruption } & Finland & 2,2 & 98,1 & 0,2 \\
\hline & Latvia & 0,3 & 66,3 & 0,1 \\
\hline
\end{tabular}


As it can be seen in Table 1, according to all positions the indicators of Latvia are lower than in Finland which has one of the best indicators Worldwide Governance in the world. Particularly unsatisfactory indicators in Latvia are Control of Corruption, Political Stability and Absence of Violence/Terrorism. According to the international assessments the biggest issue in Latvia is corruption which is extended to all the levels of government.

As it seen in the table, the quality of management of Latvia leaves much to be desired, the corruption doesn't contribute to the selection of the best individuals and legal entities for quality clustering process.

It should be noted that success of state support of formation of clusters, according to the research of Australian scientist Mark Vikhema is provided in cases, when:

- state reacts swiftly to the needs of cluster, taking into the consideration entrepreneurial, geographical and historical contexts;

- the state is able to increase the role of key factors of development of clusters;

- state methods of regulation are focused on the support of different stages of life cycle of cluster;

- the state provides the necessary infrastructure for the development of cluster, while trying to foresee the needs of entrepreneurial structures, but not to follow in the wake of the business;

- the support of the state is focused on the firm - leader, cluster core [8].

One of the pitfalls of the Latvian state management is the fact that general policy and actions of individual agencies are not coordinated with each other and suffer from a lack of continuity. It can be called institutional traps.

It is worth noting the sad reality - in Latvia there are approximately 3 million hectares of forest, of which 200000 hectares belongs to different Swedish companies. The leader of the list of the largest Latvian landowners appears the Norwegian company Storebrand Livsforsikring AS, possession of which make 493 square kilometers. We are talking about foreign mergers - national threat in Latvia, as well as clustering.

After the crisis of 2009 the Scandinavian banks have become the largest owners of real estate in Latvia, adopting it through subsidiary enterprises in the bankrupt debtors. Currently, more than $80 \%$ of the Latvian farms in Latvia have the loans on the security of land [9].

Swedes in Latvia have the largest part of the entire communications: fixed, mobile, internet and cable TV. More than $25 \%$ of allocations which gives the EU to our country returns not only to the European monopolies in the form of import, directly associated with the implementation of financial programs of the EU, but also in the form of return of a huge flow of credit by the population to Scandinavian banks.

If to consider the indicators of direct foreign investments (DFIs) in Latvia, then according to the countries of origin, then in 2014 at the top of list are Sweden (21\%), Netherlands (8\%) and Russia with Cyprus (7\%) [10]. Riga ranks the first place in the national rating from Lursoft not only in the number of investments, but also according to the paces of their savings (for the year the sum has grown up on 119 million euro), in the last year the attraction of business to Riga is not waned: more than $60 \%$ of all established Latvian enterprises in the last year have registered in the largest city. Unfortunately, in Latvia only the Riga region can be called innovative.

Besides, in Latvia the direct foreign investments $25 \%$ it is a financial intermediation, $13 \%$ - real estate transactions, $12 \%$ it is processing real estate. The four freedoms of Maastricht (the movement of capital, goods, labor force and services) have provided intrusion and subsidence of the European monopolies, leading to the ruin of small producers. The partial employment has become a universal phenomenon, the retirement age is increasing and pension reduces, unemployment is growing, where among women and youth it is the greatest.

It should be noted, as an example of a balanced, qualitative relation in management - the Italian government which is retained under the state jurisdiction a number of large companies in the military and industrial complex, in power supply, in banking sector that raises the ire of IMF leadership, insisting on the introduction of their dogmatic views in the Italy's economic policy. In total, this sector makes not less than $22 \%$ of all Italian economy and the availability of this sustainable element has saved the country from more serious decline in the conditions of crisis of $2008-2010$.

Let's consider the ratio of export and import in Latvia (Figure 1). 


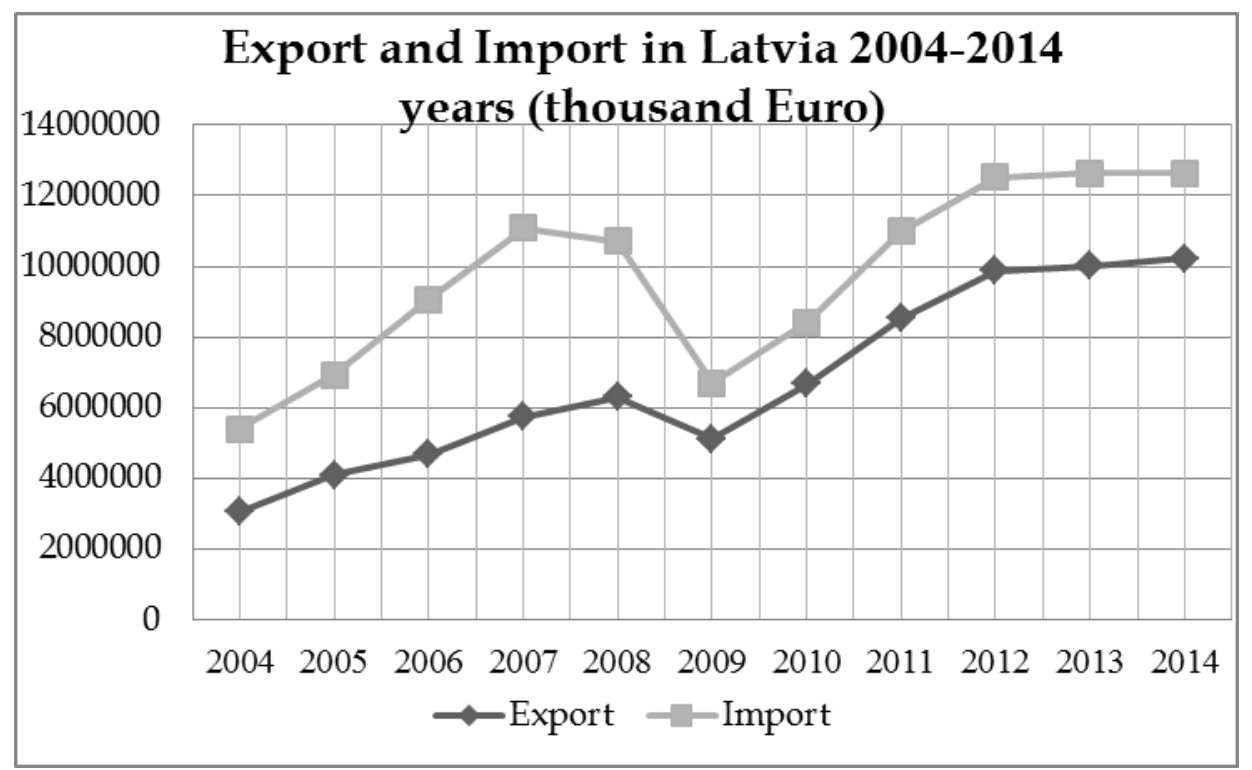

Made by the author on the basis of data Latvijas statistika [11]

Figure 1. Export and Import in Latvia 2004-2014 years

In figure, it is seen that the indicators of Latvia indicate about a constant negative balance of trade, although, for information, in the EU, on an average, the ratio of export to import is 2265 billion to 2231 billion (2014) [12]. It is the next problem of Latvia, the lack of clustering of economy.

Currently, in Latvia the most of the international associations represent only the business initiative. However, the country has the sufficient potential for the creation and development of international clusters. Therefore, the development of clusters is one of the conditions for the improvement of competitiveness and development of the economy of Latvia, where the transition to the innovative development on the basis of the newest modernization concentrates the resources in promising mutually reinforcing enterprises - clusters. The goal of the regional policy of Latvia in this situation is the establishment of sustainable territorial community.

\section{Summary and concluding}

Thus, on the above background the Latvia has the same sufficiently major shortcomings:

- small business, as a significant component of clusters is too noncompetitive and insufficiently innovative for successful functioning in clusters;

- the level of state management is mediocre - a corruption and other are obviously break the required direction of economic development in clustering;

- there is an obvious merger/intervention of foreign investors of economic units of Latvia that has a negative influence on the living standards of the population;

- the influence of financing of the EU in the economy of Latvia is only partially gives a positive effect, its significant part comes back in the form of import and credit reimbursements.

Based on the above mentioned, the author considers that it is necessary to provide the following recommendations:

We believe that improving the competitiveness of Latvia is possible only through the formation of a new model - the clustering of economy. This aspect requires improving the quality of governance.

The creation of program of national development of Latvia will provide favorable conditions for the development of the innovation process at all levels of the economy: for enterprises both private and state-owned legal entity for individual industries and regions.

The Government of Latvia is necessary to formulate the concept of learning economy which implies a continuous process of improving of skills and knowledge required for the production of innovative products. Knowledge economy implies that in this process should be involved to a greater extent all sections of society, what has a positive impact on the social sector of the economy.

The government should move away from the distributing and supervisory function to a strategic vision. The Latvian higher education must become more dynamic, open to the flow of international knowledge, to master the Western experience and to link the learning with business structures.

It should develop a better system for selecting foreign investors, especially in the strategically important state companies.

As Latvia is a basic component of clusters of small and medium-sized businesses, the need for full support for these initiatives of the private sector.

The increase of level of quality of state management on the basis of recommendations of the European Commission, using the positive experience of the other European countries. 
The carried out research has allowed demonstrating that clustering process, as a way of innovative development of Latvia is too low. The support to the cluster initiatives of private business is insufficient on the part of the state.

The experience of a number of European countries shows the importance of the availability and implementation of national programs for innovative development. We believe that improving the competitiveness of Latvia is possible only through the formation of a new model - clustering of economy. Therefore, the further research is suggested to steer into the creation of regional innovation clusters and tracking the processes that prevent the cluster development of Latvia.

\section{REFERENCES}

[1] Портер М. Э. Конкуренция. - М: Изд. дом «Вильямс», 2005.World bank. URL: http://info.worldbank.org/governan ce/wgi/index.aspx\#reports

[2] Dahmen, E. (1970) Entrepreneurial Activity and the Development of Swedish Industry, 1919-1939. The American Economic Association/ Homewood, IL.

[3] Van den Berg L., Braun E., van Winden W. Growth Clusters in
European Cities: An Integral Approach. Urban Studies, 2001.

[4] Clusters are individuals: new findings from the European cluster management and cluster program benchmarking. Danish Ministry of Science, Technology and Innovation. Berlin, 2012. Vol.

[5] Цихан Т. Кластерная теория экономического развития. «Теория и практика управления», №5, 2003 г. URL: http://www.subcontract.ru/Docum/DocumShow_DocumID_ 168.html

[6] Global innovation index 2015. URL: https://www.globalinno vationindex.org/userfiles/file/reportpdf/GII-2015-v5.pdf

[7] World bank. URL: http://databank.worldbank.org/data/report s.aspx? source $=$ Worldwide-Governance-Indicators

[8] Wikham M. Regional Economic Development: Exploring the Role of Government in the Porter's Industrial Cluster Theory. CRIC Cluster conference. Beyyond Cluster-Current Practice \& Future Strategies Ballarat, June 30 - July 1, 2005.

[9] Смирнов Д. URL: http://www.mklat.lv/mnenie/18304-dmitri j-smirnov-zachem-spekulyantam-nasha-zemlya

[10] World bank. URL: http://databank.worldbank.org/data/report s.aspx? source $=$ Worldwide-Governance-Indicators

[11] Latvijas statistika. URL: http://www.csb.gov.lv/

[12] CIA World Factbook. URL: https://www.cia.gov/library/publ ications/the-world-factbook/ 